\title{
"Investment and innovative development of industrial enterprises as the basis for the technological singularity"
}

\author{
Olena lastremska (D https://orcid.org/0000-0002-5653-6301 \\ Hanna Strokovych iD https://orcid.org/0000-0002-5092-9059 \\ R http://www.researcherid.com/rid/U-3516-2018 \\ Oleksiy Dzenis iD https://orcid.org/0000-0001-8479-6525 \\ AUTHORS R R http:/www.researcherid.com/rid/M-4629-2018 \\ Olena Shestakova iD https://orcid.org/0000-0003-2130-3193 \\ R http://www.researcherid.com/rid/A-8201-2019 \\ Timur Uman (D) http://orcid.org/0000-0002-8938-2150 \\ R http://www.researcherid.com/rid/F-6867-2014
}

Olena lastremska, Hanna Strokovych, Oleksiy Dzenis, Olena Shestakova and

ARTICLE INFO

Timur Uman (2019). Investment and innovative development of industrial enterprises as the basis for the technological singularity. Problems and

Perspectives in Management, 17(3), 477-491. doi:10.21511/ppm.17(3).2019.38

DOI

http://dx.doi.org/10.21511/ppm.17(3).2019.38

RELEASED ON

Monday, 30 September 2019

RECEIVED ON

Friday, 14 June 2019

ACCEPTED ON

Monday, 16 September 2019

(cc) EY

LICENSE

This work is licensed under a Creative Commons Attribution 4.0 International

License

JOURNAL

"Problems and Perspectives in Management"

ISSN PRINT

$1727-7051$

ISSN ONLINE

$1810-5467$

PUBLISHER

LLC "Consulting Publishing Company "Business Perspectives"

FOUNDER

LLC "Consulting Publishing Company "Business Perspectives"

NUMBER OF REFERENCES

23
NUMBER OF FIGURES

2
NUMBER OF TABLES

7

(C) The author(s) 2022. This publication is an open access article. 


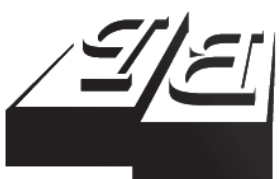

BUSINESS PERSPECTIVES

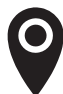

LLC "CPC "Business Perspectives" Hryhorii Skovoroda lane, 10, Sumy, 40022, Ukraine

www.businessperspectives.org

Received on: $14^{\text {th }}$ of June, 2019 Accepted on: $16^{\text {th }}$ of September, 2019

(c) Olena Iastremska, Hanna Strokovych, Oleksiy Dzenis, Olena Shestakova, Timur Uman, 2019

Olena Iastremska, Professor, Doctor of Economics, Faculty of Management and Marketing, Department of Management, Logistics and Economics, Simon Kuznets Kharkiv National University of Economics, Ukraine.

Hanna Strokovych, Doctor of Economics, Professor, Faculty of Management and Marketing, Department of Management, Logistics and Economics, Simon Kuznets Kharkiv National University of Economics, Ukraine.

Oleksiy Dzenis, Ph.D., Associate Professor, Faculty of International Economic Relations, Department of International Economics and Management of Foreign Economic Activity, Simon Kuznets Kharkiv National University of Economics, Ukraine.

Olena Shestakova, Faculty of International Economic Relations, Department of International Economics and Management of Foreign Economic Activity, Simon Kuznets Kharkiv National University of Economics, Ukraine.

Timur Uman, Senior Associate Professor in Accounting and Management Control, Jonkoping International Business School, Jonkoping University, Sweden.

\section{(c) (i)}

This is an Open Access article, distributed under the terms of the Creative Commons Attribution 4.0 International license, which permits unrestricted re-use, distribution, and reproduction in any medium, provided the original work is properly cited.
Olena Iastremska (Ukraine), Hanna Strokovych (Ukraine),

Oleksiy Dzenis (Ukraine), Olena Shestakova (Ukraine), Timur Uman (Sweden)

INVESTMENT AND

INNOVATIVE DEVELOPMENT OF INDUSTRIAL ENTERPRISES AS THE BASIS FOR THE TECHNOLOGICAL SINGULARITY

\begin{abstract}
Investment and innovative development of industrial enterprises is driven by the influence on the sensitive indicators of their activity, which characterize technological singularity. Therefore, it is expedient to define them using adequate economic and mathematical methods that will identify the development and growth points that are characterized by the accumulation of information and are a manifestation of singularity. The purpose of the article is to determine the main sensitive indicators of the investment and innovative development of industrial enterprises, which are the points of technological singularity. The article proposes conceptual provisions for evaluating the investment-innovation activity of enterprises as a basis for their development. These provisions consider the activity of economic entities according to three states (functioning, growth, and development); evaluation of investment and innovation activities, both individually and in conjunction with the official statistical reporting of enterprises using a well-founded minimum sufficient system of partial indicators defined through the multidimensional factor analysis and combined into integral and summarizing indicators; determination of technological singularity points as a result of prediction of partial and summarizing indicators' values via the neural networks method. A methodological approach is developed to substantiate the technological singularity points, the managerial influence on which is provided by the development of enterprises. The methodological approach is based on considering the investment-innovation activity nonlinearity, both explicit and latent tendencies of development, situationality and variability of its goals, strategic orientation and possible technological singularity of an enterprise. The proposals submitted were implemented based on statistical reports of the machine-building enterprises for 2014-2018.
\end{abstract}

Keywords

JEL Classification

investment, innovation, singularity, non-linear processes, sensitive indicators, activity, business entities

\section{INTRODUCTION}

Current socio-economic processes are characterized by volatility, randomness, riskiness, dynamism, and increased changes in their trends. This applies to all aspects of modern economics and management, namely, financial-economic, social, innovative, technical, technological, which can be considered as a certain manifestation of singularity that is closely analyzed by scientists. Therefore, it is necessary to carefully investigate the subject areas of singularity in economics and management related to investment and innovation processes. 


\section{LITERATURE REVIEW}

Many scientists have investigated the singularity (Caragliu, de Bo, \& Nijkamp, 2009; Kurzweil, 2008; Lombardi et al., 2012; Nicolescu, 2016; Vinge, 1993, among others). They note that singularity manifests itself in the case of critical accumulation of experience and information, that is information is a leading singularity feature.

Komninos (2006), Giffinger et al. (2007), Hollands (2008), and Caragliu et al. (2009) emphasize the importance of accumulating information for the development of socio-economic systems, given the economic viability of its possible trajectories, which contributes to the creation of knowledge, digital structures and managerial decisions.

Lombardi et al. (2012) focus on the inclusiveness and improvement of socio-economic systems through the functioning of universities, industry structures, and government. Giffinger et al. (2007) hold the similar opinion. They emphasize the importance of industry, training, and technological infrastructure that contribute to the singularity of socio-economic systems.

According to More and Vita-More (2013), the accumulation of complexity and volume of information and innovation disrupts the traditional course of life processes of simple, and most importantly, complex systems, which is a singularity. Munoz and Naqvi state that unique human characteristics, namely consciousness, intelligence, creativity, peculiar response to the demands of survival, evolutionary conditioning and human behavior, create the complexity of life as a process and system. On this basis, it is possible to draw an analogy with an enterprise, which is also advisable to consider as a functional dynamic system, which requires the use of not only material but also intangible resources, whose key role is constantly growing in achieving the technological singularity. According to Munoz and Naqvi (2017), the field of artificial intelligence prevails currently in the "technological sky", which attracts large investments and is characterized by significant results in their use. A clear distinction is made between heteronomous machines (those not capable of learning or adaptation) and autonomous machines with the prevalence of the former, which activates the singularity processes.

Along with the proponents of the singularity, there are scholars who do not recognize its existence and influence. One of the first scientists to doubt the existence of the singularity was Nicolas de Condorcet, the French mathematician of the 18th century, the philosopher and revolutionary. In his 1794 essay "Sketch for a Historical Picture of the Progress of the Human Mind", he stated that nature has not given any definition of the human ability perfection, that human perfection is truly uncertain, and that the progress of that perfection, henceforth independent of any force that might want to stop it, has no limit but the duration of the globe to which nature threw us (Condorcet, 1794, p. 5). In various fields of science, however, there are more supporters of singularity than critics.

The concept of singularity (its special aspects) is common in many fields of science and technology and is characterized by a certain specificity and variety. Summarizing the thoughts of many prominent scientists, one can conclude that there are different types of singularities, namely, cosmological, gravitational, mathematical, biological, and technological.

Kurzweil (2005) emphasizes the importance of biological singularity for human development and suggests that innovative advances will allow humans to protect their bodies from the effects of aging and to make their life expectancy limitless. He argues that technological advances in medicine will allow us to constantly renew and replace defective body components, extending life to an indefinite age, as evidenced by the achievements in biomedical engineering. In addition, the achievements in bioengineering will continue to be extended to other industries, such as food, light industry, etc. Therefore, progressive innovation is gradually accelerated and limited by the exclusively existing human brain intelligence, which has not changed fundamentally over the millennia.

As to the enterprises' activity, they tend to have a technological singularity, which is related to investment and innovation activity and causes, due to investment, the emergence, use and diffusion of innovations in general and technological innovations in particular. 
The "technological singularity" term was originally adopted by Vinge (1993), the mathematician and scientist, who argued that artificial intelligence, that is biological human enhancement or brain-computer interfaces, could be the possible causes of the singularity. He outlined the main ways in which singularities would be associated with the development of computer networks and the human interface.

Nicolescu (2016), Vinge (1993), and Kurzweil (2005) considered technological singularity as a hypothetical event in which artificial intelligence would be capable of recursive self-improvement or autonomous creation of smarter and more powerful machines than it is itself, up to an intellectual explosion that generates intelligence going beyond all current human control or understanding. That is why technological singularity characterizes innovation processes and their financial support, that is, investment processes and investment activities.

Many authors have linked singularity to observations of the exponential growth of innovations in different technologies, using such observations as a basis for predicting that singularity is likely to occur in our century. Kurzweil (2008) predicts that the singularity will occur about 2045, and according to Vinge (1993), this will take place around 2030.

Labunska et al. (2019) argue that the lack of methodological approaches to analyzing the effectiveness of innovative projects hinders innovation promotion in the Ukrainian market. The lack of appropriate methodological approaches results in companies abandoning innovations due to uncertainty of the final economic results, which should be interpreted as having a singularity. This is important to ensure the development of enterprises, but not sufficient to achieve technological singularity, which is impossible without the efficient use of investment resources.

Ponomarenko and Gontareva (2017) conducted an analysis that shows the reduction of the number of innovative enterprises by reducing the sources of financing from the state and big business, which makes it impossible to achieve technological singularity by other enterprises.
According to Nordhaus (2015), singularity can arise both from the demand side and the supply side that result from the substitution of high growth rates of inputs or outputs as well as the abandonment of traditional resources. Concerning the demand, the author emphasizes that the singularity will happen if the benefits are such that the consumption costs will increase in the high-performance industries. Concerning the supply, Nordhaus (2015) believes that the singularity will be reached if production is characterized by a sufficient degree of substitutability to allow the input volume to rapidly improve information capital, which will contribute to the improvement of all other types of capital. All this will eventually lead to the rapid development of enterprises.

Thus, the technological singularity is closest to the field of economics and management. Considering the singularity as a foreseeable short period of extremely rapid technological progress, which is supported by the vast majority of scientists in substantial terms, it is important to find a state of innovation processes that would encourage the active introduction of innovation by business entities. In this aspect, the technological singularity is the point in time after which progress becomes too active and incomprehensible to humans, and therefore uncontrollable. This idea was first described by Friedrich Engels (1861), who believed that science moves forward in proportion to the bulk of knowledge it inherited from the previous generation. According to Engels, the rate of progress increases in proportion to the square of the distance in time from its occurrence.

The time between events is shrinking rapidly, indicating the theoretical possibility and correctness of the statement. So when will the singularity point come? That is the point on the time stream that started the technological singularity, a scientific breakthrough. In the context of an enterprise, it can be interpreted as the value of indicators of investment and innovation activity, which will provide and achieve significant results in the activation of innovation activity, that is, the indicators most sensitive to changes, increasing the values of which will allow the company to achieve the best results with the lowest costs 
in the short run. Given the assumption about the management process, the values of these indicators can be considered as singularity points.

Thus, the gradual investment and innovative development of industrial enterprises is the basis for achieving technological singularity. Therefore, there is an essential need to substantiate conceptual provisions and develop a methodological approach to determine the results of investment and innovative development of industrial enterprises, which will contribute to its activation and accelerate the achievement of technological singularity.

\section{Aims}

The main purpose of the article is to identify the key sensitive indicators of investment and innovation activity that can significantly accelerate it at the level of economic entities, that is, to provide a singularity manifestation that can be justified based on the refinement of conceptual provisions and a methodological approach to investment and innovation activity assessment.

\section{RESEARCH METHODOLOGY}

To achieve the purpose of the research, a system of general scientific and special methods and approaches was used, in particular: abstract-logical and structural-logical analysis was employed to substantiate conceptual provisions of evaluating investment and innovative activity of an enterprise; multidimensional factor analysis and cluster analysis methods - to develop a methodological approach to evaluating investment and innovation activities in their relationship as to industrial enterprises; additive convolution method was used to estimate integral indicators of investment and innovation activity of enterprises and to summarize integral index of their investment and innovation activity; neural networks were applied to determine sensitive indicators of investment and innovation activity, which can be considered as singularity points, and to predict the quantitative values of the summarizing integral indicator of investment and innovation activity of industrial enterprises; graphical method was applied to demonstrate the results of the study.
A methodological approach to the evaluation of investment and innovation activity of enterprises to ensure reliability and validity should be based on the proven conceptual provisions. Therefore, the article presents substantiated basic conceptual provisions for the evaluation of investment and innovation activity of enterprises (Figure 1), whose peculiarities lie in taking into account the nonlinearity of its course; focusing (basing) on the official statistical reporting of the enterprise, which ensures the accuracy and objectivity of the evaluation; taking into account both explicit and latent trends; the use of a summarizing integral indicator that allows to take into account the situationality and variability of the goals of investment and innovation activity and strategic orientation of the enterprise.

Given the conceptual provisions of the evaluating investment and innovation activity of enterprises, the main features of the methodological approach, which should be taken into account, are as follows:

- the reliability and objectiveness of the estimates, which can be ensured by using official statistical reporting of enterprises as official sources of data;

- comparability of the initial information that can be achieved by logarithmization of the indicator values, or their representation through the relative share (specific gravity) model to a certain basic value;

- combining partial indicators that characterize certain features of investment and innovation activities into an integral indicator, taking into account the impact of each partial indicator on the course of a certain type of activity and comparing it with the best (reference) value of the corresponding partial indicator achieved by other similar (according to key economic indicators) enterprises;

- the main method allowing for distinguishing explicit and latent tendencies inherent in a certain activity is a multidimensional factor analysis; to identify groups of homogeneous enterprises, a multidimensional cluster analysis should be used; and to calculate the integral indicator for each enterprise, an additive convolution method is employed. 
Life activity in general, like an investment and innovation activity, is a non-linear and dynamic process

Investment and innovation activities (as complex processes) are analyzed separately in the external and internal environment of economic entities at the microeconomic level to identify main trends and their correlation using quantitative and qualitative assessment methods

The predominant characteristics of both inputs and output estimates are reliability and objectiveness achieved by using official statistical reporting of business entities on all economic levels and adequate assessment methods for the subject and object of research
Partial indicators of investment and innovation activities are integrated into integral ones taking into account the influence of each partial index on the course of complete business. Investment and innovation activities are assessed taking into account their integral indicators that are combined into the summarizing integral indicator given the importance of each activity for the selected activity implementation

The calculated value of the summarizing integral indicator is predicted for the required period, but not less than a year, via the neural networks, which are determined and approximated by the algorithmic construction of human thinking

The most sensitive indicators of investment and innovation activities characterize the singularity points, the influence on which will allow for intensifying innovation introduction and providing them with sufficient investment resources. This will contribute to the enterprise development in accordance with the life trajectory

Figure 1. The main conceptual provisions for assessing the investment and innovation activity of enterprises

Taking into account the peculiarities noted, the main stages of the proposed methodological approach to the evaluation of investment and innovation activity are the following:

- identifying primary partial indicators that accurately and objectively characterize a particular activity;

- identifying multiple correlation relationships between selected partial indicators to eliminate duplication of information;

- using multivariate factor analysis to reduce the number of partial indicators and to identi- fy the most significant ones for evaluating the relevant activity;

- forming a sound system of indicators for evaluating the investment and innovation activity of enterprises;

- calculation of significance coefficients for each partial indicator of investment and innovation activity according to its factor loading;

- grouping enterprises into clusters by using cluster analysis according to influential partial indicators, which are determined as a result of multi-dimensional factor analysis, to 
allocate homogeneous groups of enterprises in order. This is done to increase the validity of benchmarks chosen to calculate the integral index of a certain type of activity of each enterprise in a homogeneous group of enterprises for a certain period (one year in this case);

- interpreting values of integral and summarizing indicators of investment and innovation activity of enterprises for making sound management decisions about their progress;

- predicting the values of the summarizing indicator of investment-innovation activity and identifying their most sensitive indicators as singularity points for managerial influence in order to intensify investment and innovation processes.

The methodological approach to assessing investment and innovation activity was applied to a set of machine-building enterprises of the Kharkiv region, which had positive financial results, carried out investment activity and developed, produced and sold innovative products for industrial and technical purposes.

\section{EMPIRICAL RESULTS}

In order to evaluate investment activity, the following partial indicators have been used, which characterize the activity and can be calculated using the forms of official statistical reporting during the last 5 years: $x_{1}$ is the share of fixed capital investment in the total capital; $x_{2}$ is the share of equity investment in equity funds; $x_{3}$ is the share of capital investment in total capital; $x_{4}$ is the share of capital investment in equity funds; $x_{5}$ is the share of tangible investment in the total amount of capital investment; $x_{6}$ is the share of investment in advertising in the total amount of investment in innovation; $x_{7}$ is the share of investment in innovations in the total amount of capital investment; $x_{8}$ is the share of investment in computer hardware and software in the total amount of intangible investments; $x_{9}$ is the share of intangible investment in the total value of non-current assets; $x_{10}$ is the share of intangible investment in the total value of assets.
Accordingly, it is proposed to use the following set of partial indicators to estimate innovation based on reporting statistics: $X_{1}$ is the share of investment in innovation in total capital; $X_{2}$ is the share of equity investment in total capital; $X_{3}$ is the share of $R \& D$ expenditure in total innovation costs; $X_{4}$ is the share of the costs on machinery, equipment and software related to the implementation of innovation, in the total amount of innovation costs; $X_{5}$ is the share of inventors and innovators in the average number of staff; $X_{6}$ is the share of own investments in technological innovations in the total amount of innovation expenses; $X_{7}$ is the share of budget investment in technological innovations in the total volume of investment in innovations; $X_{8}$ is the share of domestic investors' investment in the total innovation expenses; $X_{9}$ is the proportion of foreign investors' investment in the total cost of innovations; $X_{10}$ is the share of shipped innovative products in the total volume of sales; $X_{11}$ is the share of the shipped products, characterized by significant technological changes or re-introduced within three years, in the total volume of the products shipped; $X_{12}$ is the share of the shipped products, for which the manufacturing process has been improved, in the total volume of the shipped products; $X_{13}$ is the share of transmitted new technologies in Ukraine in the total amount of technologies transmitted; $X_{14}$ is the share of transmitted new technologies abroad in the total amount of technologies transmitted; $X_{15}$ is the share of new products in total production; $X_{16}$ is the proportion of new products put up for export in the total amount of new products.

As is commonly known, the socio-economic phenomenon can be characterized by several features. With a significant set of such features in the correlation-regression analysis, detecting and interpreting the impact of the ties become difficult. Therefore, according to Pliuta (1980), there is a need for compaction of information, that is, the description of the phenomenon (object) investigated using more integrated indicators, the socalled "key components". Correlation matrix contains the initial information needed for inclusion of indicators in the evaluation. Based on this matrix, using the principal component method, the evaluation of values of the studied indicators (features) can be continued. 
Table 1. Dispersion and eigenvalues of main components of the investigated enterprises' investment activity

\begin{tabular}{c|c|c|c|c}
\hline Component & Eigenvalue & $\begin{array}{c}\text { Total dispersion } \\
\text { percentage, \% }\end{array}$ & $\begin{array}{c}\text { Cumulative eigenvalue } \\
\text { of total dispersion, \% }\end{array}$ & $\begin{array}{c}\text { Cumulative percentage } \\
\text { ond }\end{array}$ \\
\hline I & 2.9270 & 29.2703 & 2.9270 & 29.2703 \\
II & 2.2088 & 22.0884 & 5.1359 & 51.3587 \\
\hline III & 1.8231 & 18.2314 & 6.9590 & 69.5901 \\
IV & 1.4813 & 14.8128 & 8.4403 & 84.4029 \\
\hline
\end{tabular}

Table 2. Dispersion and eigenvalues of the main components of the investigated enterprises' innovation activities

\begin{tabular}{c|c|c|c|c}
\hline Component & Eigenvalue & $\begin{array}{c}\text { Total dispersion } \\
\text { percentage, } \%\end{array}$ & Cumulative eigenvalue & $\begin{array}{c}\text { Cumulative percentage } \\
\text { of total dispersion, \% }\end{array}$ \\
\hline I & 2.3866 & 23.8660 & 2.3866 & 23.8660 \\
\hline II & 1.8955 & 18.9550 & 4.2821 & 42.8210 \\
\hline III & 1.43569 & 14.3569 & 5.7178 & 57.1780 \\
\hline IV & 0.9382 & 9.3820 & 6.6560 & 7.1727 \\
\hline$V$ & 0.51669 & 5.1669 & 7.3848 & 71.7270 \\
\hline VI & 0.21210 & 2.1210 & 73.8480 \\
\hline
\end{tabular}

In order to reduce the initial data, the most informative factors that form the main components have been identified. The universal integrated system STATISTICA 12 was used for this purpose. While using the multidimensional factor analysis, it is possible to investigate the structure of the relationship between variables and reduce the number of regressors, that is, indicators in the model.

The use of the Varimax Factor Rotation Method made the factors easy for interpretation because it allowed minimizing the number of variables with high factor loading while maintaining the factor orthogonality. As a result, the main components were selected according to the indicator of total (cumulative) dispersion, namely $84.4029 \%$ by in- vestment activity (Table 1) and $73.848 \%$ according to innovation activity (Table 2).

Factor loading with the value not exceeding 0.7 is the criterion for selecting and including a partial indicator in the system of indicators to evaluate investment (Table 3) and innovative (Table 4) activities.

The structure of the components as to highlighting important partial indicators of the investment activity is the following: component I (investment in information support for innovations): $x_{6}-$ the share of investment in advertising in the total amount of investment in innovation; $x_{7}$ - the share of investment in innovations in the total amount

Table 3. Factor loading of investment activity indicators of machine-building enterprises of the Kharkiv region

\begin{tabular}{|c|c|c|c|c|}
\hline \multirow{2}{*}{ Indicator } & \multicolumn{4}{|c|}{ Component } \\
\hline & I & II & III & IV \\
\hline The share of fixed capital investment in the total capital $\left(x_{1}\right)$ & -0.1237 & 0.9343 & 0.0228 & 0.0115 \\
\hline The share of equity investment in equity funds $\left(x_{2}\right)$ & 0.0247 & 0.0957 & -0.0165 & 0.9648 \\
\hline The share of capital investment in total capital $\left(x_{3}\right)$ & -0.0519 & 0.9351 & 0.0823 & 0.0986 \\
\hline The share of capital investment in equity funds $\left(x_{4}\right)$ & 0.0808 & 0.0066 & -0.0147 & 0.9690 \\
\hline The share of tangible investment in the total amount of capital investment $\left(x_{5}\right)$ & -0.6501 & 0.2987 & -0.0526 & 0.0060 \\
\hline $\begin{array}{l}\text { The share of investment in advertising in the total amount of investment in } \\
\text { innovation }\left(x_{6}\right)\end{array}$ & 0.9568 & -0.0610 & 0.1668 & 0.0584 \\
\hline $\begin{array}{l}\text { The share of investment in innovations in the total amount of capital } \\
\text { investment }\left(x_{7}\right)\end{array}$ & 0.9562 & -0.0596 & 0.1679 & 0.0593 \\
\hline $\begin{array}{l}\text { The share of investment in computer hardware and software in the total } \\
\text { amount of intangible investments }\left(x_{8}\right)\end{array}$ & 0.4319 & 0.3494 & -0.1936 & 0.1324 \\
\hline The share of intangible investment in the total value of non-current assets $\left(x_{9}\right)$ & 0.0934 & 0.0428 & 0.9785 & -0.0103 \\
\hline The share of intangible investment in the total value of assets $\left(x_{10}\right)$ & 0.1941 & 0.0438 & 0.9665 & -0.0215 \\
\hline
\end{tabular}


Table 4. Factor loadings of innovation activity indicators of machine-building enterprises of the Kharkiv region

\begin{tabular}{|c|c|c|c|c|c|c|}
\hline \multirow{2}{*}{ Indicator } & \multicolumn{6}{|c|}{ Component } \\
\hline & I & II & III & IV & $\mathbf{V}$ & VI \\
\hline The share of investment in innovation in total capital $\left(X_{1}\right)$ & -0.2409 & -0.0788 & 0.6454 & 0.0702 & -0.1475 & -0.1444 \\
\hline The share of equity investment in total capital $\left(X_{2}\right)$ & -0.1808 & -0.1364 & 0.4688 & -0.0952 & -0.0168 & 0.1337 \\
\hline The share of R\&D expenditure in total innovation costs $\left(X_{3}\right)$ & -0.0074 & 0.8458 & 0.0191 & 0.0464 & 0.0306 & 0.2090 \\
\hline $\begin{array}{l}\text { The share of the costs on machinery, equipment, and software related to the } \\
\text { implementation of innovation, in the total amount of innovation costs }\left(X_{4}\right)\end{array}$ & -0.0903 & -0.0189 & 0.9026 & 0.0276 & -0.0633 & 0.0136 \\
\hline The share of inventors and innovators in the average number of staff $\left(X_{5}\right)$ & 0.1506 & -0.2011 & -0.1618 & 0.1342 & 0.8823 & 0.0888 \\
\hline $\begin{array}{l}\text { The share of own investments in technological innovations in the total } \\
\text { amount of innovation expenses }\left(X_{6}\right)\end{array}$ & 0.0096 & 0.0778 & 0.6419 & 0.0252 & 0.6653 & 0.1740 \\
\hline $\begin{array}{l}\text { The share of budget investment in technological innovations in the total } \\
\text { volume of investment in innovations }\left(X_{7}\right)\end{array}$ & 0.0023 & 0.1074 & 0.5212 & 0.0362 & 0.5272 & 0.1693 \\
\hline $\begin{array}{l}\text { The share of domestic investors' investments in the total innovation } \\
\text { expenses }\left(X_{8}\right)\end{array}$ & 0.0968 & 0.7061 & -0.0222 & 0.4564 & -0.1390 & -0.0234 \\
\hline $\begin{array}{l}\text { The proportion of foreign investors' investment in the total cost of } \\
\text { innovations }\left(X_{9}\right)\end{array}$ & 0.1278 & 0.7454 & -0.0803 & 0.2658 & -0.1543 & 0.0977 \\
\hline The share of shipped innovative products in the total volume of sales $\left(X_{10}\right)$ & 0.9634 & 0.0068 & -0.0945 & -0.0241 & 0.0571 & 0.1095 \\
\hline $\begin{array}{l}\text { The share of the shipped products, characterized by significant technological } \\
\text { changes or re-introduced within three years, in the total volume of the } \\
\text { products shipped }\left(X_{11}\right)\end{array}$ & 0.2290 & 0.2927 & 0.1066 & 0.7164 & -0.0771 & 0.2343 \\
\hline $\begin{array}{l}\text { The share of the shipped products, for which the manufacturing process has } \\
\text { been improved, in the total volume of the shipped products }\left(X_{12}\right)\end{array}$ & 0.0792 & 0.3751 & 0.2257 & -0.4273 & 0.5231 & -0.3497 \\
\hline $\begin{array}{l}\text { The share of transmitted new technologies in Ukraine in the total amount of } \\
\text { technologies transmitted }\left(X_{13}\right)\end{array}$ & 0.1532 & 0.1901 & 0.0617 & -0.0203 & 0.1099 & 0.8986 \\
\hline $\begin{array}{l}\text { The share of transmitted new technologies abroad in the total amount of } \\
\text { technologies transmitted }\left(X_{14}\right)\end{array}$ & -0.0336 & 0.1659 & 0.0215 & 0.8475 & 0.2025 & -0.1533 \\
\hline The share of new products in total production $\left(X_{15}\right)$ & 0.9634 & 0.0068 & -0.0945 & -0.0241 & 0.0571 & 0.1095 \\
\hline $\begin{array}{l}\text { The proportion of new products put up for export in the total amount of } \\
\text { new products }\left(X_{16}\right)\end{array}$ & 0.7849 & 0.1835 & 0.1242 & 0.3008 & 0.2759 & -0.1328 \\
\hline
\end{tabular}

of capital investment; component II (investment in fixed capital): $x_{1}$ - the share of fixed capital investment in the total capital; $x_{3}$ - the share of capital investment in total capital; component III (intangible investment): $x_{9}$ - the share of intangible investment in the total value of non-current assets; $x_{10}$ - the share of intangible investment in the total value of assets; component IV (equity investment): $x_{2}$ - the share of equity investment in equity funds; $x_{4}$ - the share of capital investment in equity funds.

Accordingly, the structure of each component for highlighting important partial indicators of innovation activity is as follows: component I (marketing of products in domestic and foreign markets): $X_{10}$ - the share of shipped innovative products in the total volume of sales; $X_{15}$ - the share of new products in total production; $X_{16}$ - the proportion of new products put up for export in the total amount of new products; component II (R\&D investment): $X_{8}$ - the share of domestic investors' investments in the total innovation expenses; $X_{9}$ the proportion of foreign investors' investment in the total cost of innovations; $X_{3}$ - the share of $\mathrm{R} \& \mathrm{D}$ expenditure in total innovation costs; component III (purchase and upgrade of machines, equipment and software): $X_{4}$ - the share of the costs on machinery, equipment and software related to the implementation of innovation, in the total amount of innovation costs; component IV (introduction of technology innovations and their promotion to foreign markets): $X_{11}$ - the share of the shipped products, characterized by significant technological changes or re-introduced within three years, in the total volume of the products shipped; $X_{14}$ the share of transmitted new technologies abroad in the total amount of technologies transmitted; component $\mathrm{V}$ (availability of competent specialists for innovation activities): $X_{5}$ - the share of inventors and innovators in the average number of staff; component VI (promotion of technological innovations in domestic markets): $X_{13}$ - the share of transmitted new technologies in Ukraine in the total amount of technologies transmitted.

Thus, the indicators resulting from the multivariate factor analysis are such that accurately and objectively characterize the investment and innova- 
tion activities for the set of the studied enterprises, and they should be included in the system of its evaluation as partial indicators, which make it possible to calculate the integral indicators of investment and innovation activities.

To maintain reliability and objectivity, when comparing indicators in the process of evaluating investment and innovation activities, it is advisable to group the enterprises into homogeneous groups by indicators allocated as a result of multidimensional factor analysis. This will allow calculating their integral indicators of investment and innovation activities as relative values within the 0 to 1 intervals, and that is preferred when approaching 1.

The use of the tree clustering method (hierarchical clustering) made it possible to determine the number of clusters in the set of machine-building enterprises of the Kharkiv region, whose investment and innovation activities are being investigated. Subsequent use of the $k$-means clustering allows determining the structure of clusters of homogeneous machine-building enterprises of the Kharkiv region. The k-means clustering method is the most widespread and most studied of all clustering techniques. The prevalence of the $k$-means method is due to its principal advantages: simplicity, flexibility, fast convergence. The $k$-means method is implemented on the principle of a single bond (the close neighbor method), which involves joining an enterprise to a cluster if it is close to at least one representative of this cluster by the studied indicators. The cluster structure of the machine-building enterprises of the Kharkiv region is shown on the dendrogram (Figure 2).

Using the $k$-means method made it possible to create six clusters by investment activity at the most and four related enterprise clusters according to innovation activity.

As the results of multidimensional factor analysis determined significant indicators to characterize investment and innovation activities, and the results of cluster analysis grouped the companies by the similarity of the results in investment and innovation activities, their integral evaluation was conducted using the integral indicators of each activity calculated through the additive convolution method:

$$
I_{n}=\sum_{i=1}^{m} w_{i} \cdot \frac{x_{i n k}}{x_{i e n k}}
$$

where $I_{n}$ is an integral indicator of corresponding activity of the $n$ enterprise; $m$ is the number of partial indicators of the corresponding activity of the enterprise; $w_{i}$ is a significance factor of the $i$ partial indicator of corresponding activity; $x_{i n k}$ is the value of the $i$ partial indicator of corresponding activity of the $n$ enterprise of the $k$ cluster; $x_{\text {ienk }}$ is the value of the $i$ partial benchmark of corresponding activity of the $n$ enterprise of the $k$ cluster.

As the benchmark, its best value among the enterprises that have been included in the cluster during the survey year is selected.

To determine the significance factors of the partial indicators, they are normalized by factor loadings, which allows to avoid the influence of subjective factors on the study results and to obtain a quantitative assessment, taking into account the objective impact of each indicator on the phenomenon under study:

$$
w_{i}=\frac{f_{i}}{\sum_{i=1}^{m} f},
$$

where $w_{i}$ is a significance factor of the $i$ partial indicator of corresponding activity, which is influential; $f_{i}$ is the factor loading of the $i$ partial factor of corresponding activity, which is influential.

While using the same methodology, a summarizing integral indicator of investment and innovation activity is calculated. It should be borne in mind that not only partial but integrated indicators for each activity are integrated to determine it. For this purpose, the additive convolution method was used with factor loadings normalization of all partial indices that participated in the previous calculations.

While identifying the singularity points, it is important to determine not so much the retrospective values of the summarizing integral indicator of investment and innovation activity as the predictive ones and on their basis, the performance indicators that are most sensitive to changes in the course of 


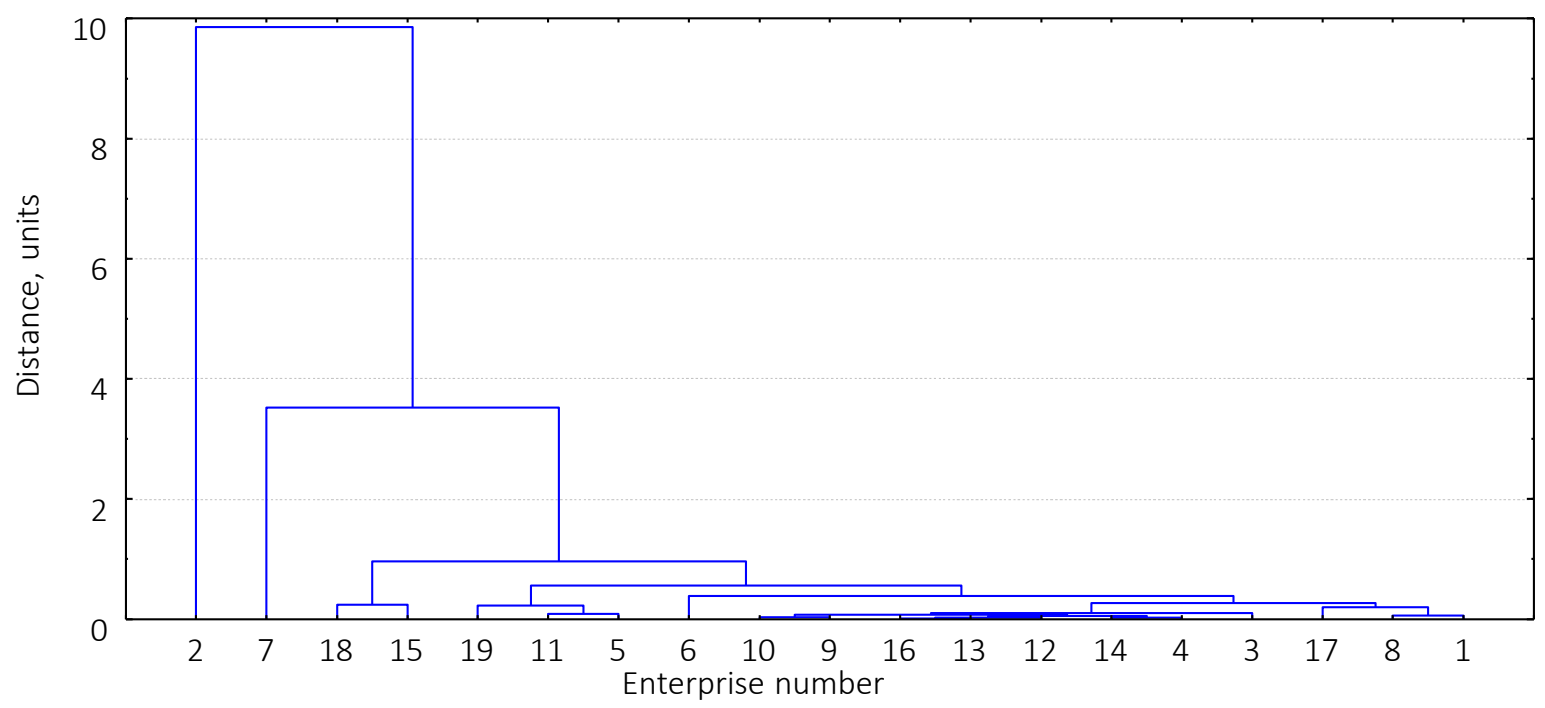

a) according to the investment activity indicators

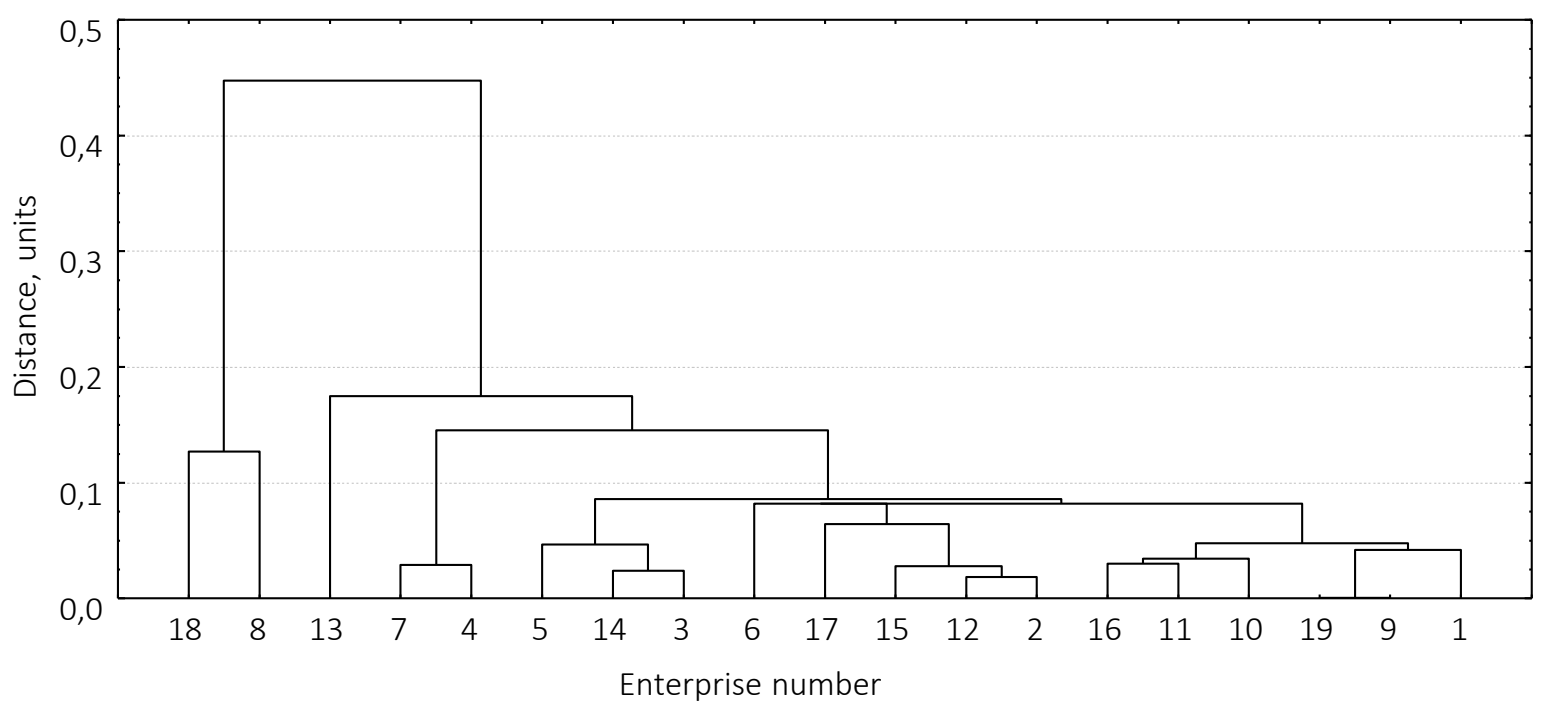

b) according to the innovation activity indicators

Figure 2. The dendrogram constructed based on investment and innovation activity indicators

the enterprises' investment and innovation activity. Particularly partial indicators that are sensitive to changes can be considered as singularity points of investment and innovation activity. Since neural networks are the closest method to human thinking algorithms that can be used to justify the presence of singularity points, the values of this indicator, taking into account the partial indicators of investment and innovation activity, selected as a result of using the multivariate factor analysis as input, is forecasted using the method.
The above method has the following principal advantages: an approximation to cognitive thinking, the ability to learn models, taking into account the management process non-linearity, which corresponds to the conceptual provisions of assessing investment and innovation activities. According to Kizim, Iastremska, and Senchukov (2007), it is expedient to use Statistica Neural Networks (StatSoft Inc.), an application software package, which provides a wide choice of different types of neural networks. Neural network models for the 
surveyed industrial enterprises have also been designed and investigated in order to determine the most suitable model for predicting a summarizing integral index.

Partial indicators of investment and innovation activity, resulting from a multidimensional factor analysis, were used as input indicators of the models, while the output index was a summarizing integral indicator of investment and innovation activity. In the interactive mode, using the Sensitivity Analysis module, based on the analysis of sensitivity to each of the input indicators, the most suitable neural network models are constructed.

In total, 24 neural network models were formed: three models of radial-basis functions, six linear, and 15 models of a multilevel perceptron. The preference for the number of nonlinear multilevel perceptron models corresponds to the conceptual position of evaluating investment and innovation activity with respect to its nonlinearity and dynamics.

By comparing error values, model efficiency, number of indicators and latent layers, the best multilevel perceptron model number 24 was selected. The model has an error value of $0.03903,18$ input indicators, one latent layer consisting of nine indicators, model efficiency value of 0.4317142 ; given characteristics confirm its adequacy to the phe- nomenon investigated, namely innovation and investment activity. The best model characterizes investment-innovation activity as complex and non-linear, which confirms sound conceptual provisions for its evaluation.

The quality of the selected model is proved by the indicators presented in Table 5. They testify to the possibility to qualitatively use it while forecasting a summarizing integral indicator of investment and innovation activity.

Such indicators are the correlation coefficient of 0.957343, the Error S.D. to Data S.D. ratio (rationality coefficient), characterizing the error to the model informativeness (0.389) ratio.

Comparison of error, efficiency, and sensitivity rates allowed us to make a rational decision on the type of neural network model to predict the summarizing integral indicator of investment and innovation activity.

The sensitivity of the partial indicators is presented in Table 5. It is advisable to use these indicators when making managerial decisions on improving the results of investment and innovation activity and its development by changing their quantitative values; that is, the identified indicators are the technological singularity points of economic entities' life.

Table 5. Quality characteristics of the multilevel perceptron model

\begin{tabular}{l|c|c}
\hline \multicolumn{1}{c}{ Characteristic } & Code name & Value \\
\hline The mean value of the output & DataMean & 0.29687 \\
\hline The mean square deviation of the output values & Data S.D. & ErrorMean \\
\hline Output mean error & Error S.D. & 0.0698253 \\
\hline The mean square deviation of the output's error values & Abs E. Mean & 0.02786 \\
\hline The absolute average error of the output's value & S.D. Ratio & 0.00961 \\
\hline The Error S.D. to Data S.D. ratio & Correlation & 0,389 \\
\hline Correlation coefficient & & 0.957343 \\
\hline
\end{tabular}

Table 6. Rank, calculation error and indicator sensitivity of the selected multilevel perceptron model

\begin{tabular}{|c|c|c|c|c|c|c|c|c|c|c|}
\hline Characteristic & $X_{1}$ & \multicolumn{2}{|c|}{$X_{2}$} & $X_{3}$ & $X_{4}$ & $X_{6}$ & \multicolumn{2}{|c|}{$X_{7}$} & $X_{9}$ & $X_{10}$ \\
\hline \multicolumn{11}{|c|}{ Partial indicators of the investment activity } \\
\hline Rank & 4 & \multicolumn{2}{|c|}{7} & 10 & 14 & 15 & \multicolumn{2}{|c|}{16} & 5 & 13 \\
\hline Error & 0.0183 & \multicolumn{2}{|c|}{0.0169} & 0.0145 & 0.0132 & 0.0131 & \multicolumn{2}{|c|}{0.0125} & 0.0180 & 0.0134 \\
\hline Ratio & 1.4923 & \multicolumn{2}{|c|}{1.3798} & 1.1837 & 1.0776 & 1.0677 & \multicolumn{2}{|c|}{1.0183} & 1.4674 & 1.0966 \\
\hline \multicolumn{11}{|c|}{ Partial indicators of the innovation activity } \\
\hline Characteristic & $X_{3}$ & $X_{4}$ & $X_{5}$ & $X_{9}$ & $X_{10}$ & $X_{11}$ & $X_{13}$ & $X_{14}$ & $X_{15}$ & $X_{16}$ \\
\hline Rank & 6 & 18 & 17 & 9 & 3 & 2 & 1 & 11 & 12 & 8 \\
\hline Error & 0.0173 & 0.0124 & 0.0124 & 0.0146 & 0.0184 & 0.0191 & 0.0363 & 0.0139 & 0.0138 & 0.0157 \\
\hline Ratio & 1.4092 & 1.0095 & 1.0141 & 1.1937 & 1.5026 & 1.5557 & 2.9637 & 1.1344 & 1.1277 & 1.2835 \\
\hline
\end{tabular}


Thus, in accordance with the singularity points, enterprises generally need to pay attention to managing the most sensitive indicators, i.e. the management of innovation processes, namely indicators such as the share of transmitted new technologies in Ukraine in the total number of transmitted technologies (rank 1), the share of shipped products that have undergone significant technological changes or been reintroduced within three years, in the total volume of goods shipped (rank 2); the share of shipped innovative products in total sales (rank 3). The identified indicators characterize the technological singularity of enterprise operation and prove the predominance of innovation for their development. Managing them will allow enterprises to improve their investment and innovation performance.

In accordance with the quantitative values of the model quality criteria, the main of which is the sensitivity of the input indicators (Table 1), and the Ratio value greater than 1 , the feasibility of using the proposed partial indicators to evaluate the investment-innovation activity is confirmed and the validity of the performance indicators of investment and innovation activities is also verified.

Table 6 presents the forecast values of the summarizing integral indicator of investment and innovation activity of enterprises for 2019 .
Analyzing the predicted values of the summarizing integral index of investment and innovation activity of industrial enterprises, one can conclude that the tendency of their change is ambiguous. At eight enterprises, these values will deteriorate if they do not develop investment and innovation activity projects, which confirms the decrease in quantitative values of summarizing integral indicator.

To make sound management decisions based on the evaluation of investment and innovation activity, quantitative values of the summarizing integral indicator of investment and innovation activity should be classified into qualitative levels. According to Kizim, Iastremska, and Senchukov (2007), it is expedient to use the Harrington scale adapted to the economic conditions in Ukraine, which was developed for machine-building enterprises.

The use of fuzzy set theory provisions for constructed membership functions, which characterize the boundaries of clear and fuzzy intervals, gives the following levels: from 0 to 0.19 - low, from 0.19 to 0.30 - medium or low, from 0.30 to 0.37 - medium, from 0.37 to 0.56 - high or medium and from 0.56 to 1.0 - a high level.

Since the implementation of fuzzy intervals makes it difficult to make managerial decisions about the

Table 7. Predictive value of the summarizing integral indicator of investment and innovation activity of enterprises for 2019 using the multilevel perceptron model

\begin{tabular}{|c|c|}
\hline Enterprise & The summarizing integral indicator value \\
\hline Kharkiv Bearing Plant & 0.3593 \\
\hline Electromashina & 0.3220 \\
\hline Kharkiv Machine-tool Building Plant & 0.1580 \\
\hline Kharkivskyi Elektroaparatnyi Zavod & 0.1915 \\
\hline HELZ PUBJSC & 0.3070 \\
\hline Vovchansk Standard Unit Plant & 0.4104 \\
\hline Kharkiv Tractor Plant & 0.2735 \\
\hline Transzv'yazok, Kharkiv Electrical Engineering Plant & 0.2611 \\
\hline Promzv'yazok, PAT & 0.3220 \\
\hline Svitlo Shakhtaria Kharkiv Machine Building Plant & 0.2176 \\
\hline Frunze Kharkiv Plant & 0.1862 \\
\hline KHZSHP & 0.2223 \\
\hline Teploautomat R\&D enterprise & 0.4238 \\
\hline TPK NOVA, Togoviy Dim & 0.2849 \\
\hline Merefa mechanical plant & 0.2675 \\
\hline Turboatom, Open Joint-Stock Company & 0.3148 \\
\hline FED, Kharkiv Machine Building Plant & 0.3416 \\
\hline Ukrpolitekhservis Private R\&D enterprise & 0.1884 \\
\hline Kupiansk Machine Building Plant & 0.1516 \\
\hline
\end{tabular}


direction of changes in investment and innovation activity, it is advisable to move to clear intervals of "low", "medium" and "high" via splitting fuzzy intervals into the congruent segments. This can be done in accordance with the typical distribution of membership functions. Thus, the limits of clear intervals of qualitative levels of the summarizing indicator of investment and innovation activity of enterprises are as follows: low level - [0.0-0.245], medium [0.245-0.455], high [0.455-1.0]. Using the presented limits of clear intervals of the summarizing integral index of investment and inno- vation activity, the studied enterprises, according to its forecast values, will be distributed as follows: eight enterprises fall into the interval of low summarizing integral indicator (42.1\%), 11 enterprises get themselves to the medium level (57.89\%). This distribution confirms the need to improve the results of investment and innovation activities and the desire for their development. This can be achieved by developing special measures that will contribute to the achievement of the main goal the development of investment and innovation activities.

\section{CONCLUSION}

Given theoretical generalization of research on singularity, technological singularity, peculiarities of investment-innovation activity and development, conceptual provisions for estimating investment-innovation activity are grounded, taking into account nonlinearity and dynamics of their course and singularity in manifestation. The proposed conceptual provisions are the basis for the developed methodological approach to evaluating the investment and innovation activities of enterprises.

A methodological approach to the evaluation of investment and innovation activity of the enterprise is proposed, which allows determining the main most sensitive indicators of investment and innovation activity, i.e., technological singularity points that can significantly accelerate its activity at the level of economic entities, i.e. to ensure the manifestation singularity.

The methodological approach to evaluate investment and innovation activities of the enterprise is built using multidimensional factor and cluster analyzes. The first allowed to identify the most important partial indicators of investment and innovation activities that can provide an innovative breakthrough for enterprises, that is, their technological singularity. Metrics selected by the additive convolution method are combined into an integral one, which is calculated by enterprise clusters, separated according to the identified indicators during multidimensional factor analysis. The methodological approach is tested using 19 engineering enterprises for the period from 2014 to 2018.

The main stages of a methodological approach to assessing investment and innovation activities are as follows: identifying primary partial indicators that reliably and objectively characterize a particular activity; identifying multiple correlation relationships between selected partial metrics to eliminate duplication of information; using multidimensional factor analysis to reduce the number of partial indicators and to highlight the most relevant ones for evaluation; forming a sound system of indicators for evaluating the activity of enterprises; calculating the significance indices for each partial indicator of investment and innovation activity by its factor loading; grouping of enterprises into clusters using cluster analysis of influential partial indicators, selected as a result of multivariate factor analysis, to distinguish homogeneous groups of enterprises in order to increase the validity of the choice of reference indicators for calculating the integral index of a certain type of activity of each enterprise in a homogeneous group of enterprises within a year; interpreting values of integral indicators of investment and innovation activity of enterprises to make sound management decisions about its progress.

The value of the generalized integral index of investment and innovation activity of the investigated enterprises for 2019 is forecasted based on the neural network method according to the best multilevel perceptron model, which proves the nonlinearity and dynamics of the progress of investment and inno- 
vation activity. The analysis of the obtained values indicates their possible deterioration, which requires the enterprises to make decisions on effective measures, which would be able to provide activation of investment and innovation activity.

Based on the use of the neural network method, the article identified the most sensitive to changes indicators of investment and innovation activity, which should be understood as technological singularity points. Exercising managerial influence on the identified indicators will ensure activation of investment and innovation activity of enterprises with minimal costs in the shortest possible time. In accordance with the singularity phenomenon, the accumulation of this information will allow increasing exponentially the level of innovation of enterprises as a whole, which will allow them to ensure their competitiveness and strengthen their position in the markets.

\section{ACKNOWLEDGMENT}

The following materials were used in writing this article: Strategic management of the enterprises' activity based on investing to ensure a decent quality of working life (state registration number: 0115U002374); Development of methodological support to activate innovative activity of an industrial enterprise (state registration number 0115U007161); Management of innovation and logistics (state registration number 0117U007636).

\section{REFERENCES}

1. Caragliu, A., de Bo, C., \& Nijkamp, P. (2009). Smart cities in Europe. 3rd Central European Conference in Regional Science, CERS. http:// doi.org/10.1080/10630732.2011. 601117

2. Engels, F. (1961). Наброски к критике политической экономии [Nabroski k kritike politicheskoy ekonomii]. Retrieved from http://www.uaio.ru/marx/01. htm

3. Giffinger, R., Fertner, C., Kramar, H., Kalasek, R., Pichler-Milanovic, N., \& Meijers, E. (2007). Smart Cities - Ranking of European medium-sized cities. Retrieved from http://curis.ku.dk/ws/ files/37640170/smart_cities_final_report.pdf

4. Hollands, R. G. (2008). Will the real smart city please stand up? City, 12(3), 303-320. https://doi. org/10.1080/13604810802479126

5. Iastremska, O. M. (2006). Застосування теорії нечітких множин для якісного розмежування характеристик підприємств (на прикладі підприємств машинобудівної, харчової та легкої промисловості) [Zastosuvannia teorii nechitkykh mnozhyn dlia yakisnoho rozmezhuvannia kharakterystyk pidpryiemstv (na prykladi pidpryiemstv mashynobudivnoi, kharchovoi ta lehkoi promyslovosti)]. Ekonomika rozvytku, 3(39), 95-101.

6. Iastremska, O. M., \& Stokovych, H. (2019). Main trends of investment and innovative activity of business entities in the conditions of European integration. Innovative Tachnologies and Scientific Solutions for Industries, 1(7). https://doi.org/10.30837/25229818.2019.7.130

7. Kizim, N. A., Iastremska, E. N., \& Senchukov, V. F. (2007). Нейронные сети: теория и практика применения [Neyronnyye seti: teoriya i praktika primeneniya]. Retrieved from https://bok.org/book/3203879/e45260

8. Komninos, N. (2006). The architecture of intelligent cities: integrating human, collective and artificial intelligence to enhance knowledge and innovation. In the IEEE 2nd IET International Conference on Intelligent Environ- ments (pp. 13-20). Retrieved from https://www.researchgate.net/ publication/252536162_The_Architecture_of_Intelligent_Cities

9. Kurzweil, R. (2005). The singularity is near. New York: Penguin. Retrieved from http://stargate.inf. elte.hu/ seci/fun/Kurzweil,\%20 Ray\%20-\%20Singularity\%20 Is\%20Near,\%20The\%20\%28hardback $\% 20$ ed $\% 29 \% 20 \% 5$ Bv $1.3 \% 5 \mathrm{D}$. pdf

10. Kurzweil, R. (2008). The singularity: The last word (electronic forum). Retrieved from http:// ieeexplore.ieee.org.mutex.gmu. edu/stamp/stamp.jsp?tp=\&arnum ber $=4635038 \&$ isnumber $=463503$ 2\&tag=1)

11. Labunska, S. V., Karaszewski, R., Prokopisyna, O. V, \& Iermachenko, Ie. V. (2019). Cognitive analytical tools for cost management of innovation activity. Problems and Perspectives in Management, 17(1), 395-407. https://doi.org/10.21511/ ppm.17(1).2019.34

12. Lombardi, P., Giordano, S., Caragliu, A., Del Bo, C., Deakin, M., Nijkamp, P., Kourtit, K., \& Farouh, H. (2012). An advanced triple- 
helix network model for smart cities performance. Retrieved from https://research.vu.nl/en/publications/an-advanced-triple-helixnetwork-model-for-smart-citiesperforman

13. More, M., \& Vita-More, N. (Eds.) (2013). The transhumanist reader: Classical and contemporary essays on the science, technology, and philosophy of the human future. West Sussex, UK: Wiley-Blackwell. Retrieved from https://books. google.com.ua/books?hl=uk\&lr= \&id=YeFo_20rfz0C\&oi=fnd\&pg= PT5\&dq =More, + M., $+\% 26+$ Vita-

14. Munoz, J. M., \& Naqvi, A. (2017). Artificial Intelligence and Urbanization: The Rise of the Elysium City. Econom ics and Political Economy, 4(1), 1-13. Retrieved from https:// pdfs.semanticscholar.org/574e/ d14ad06cd6cd164991c696d6c11c197b4fc7.pdf

15. Nicolescu, B. (2007). Transdisciplinarity as methodological framework for going beyond the science and religion debate. Transdisciplinarity in Science and Religion, 2, 35-60. Retrieved from https://metanexus.net/transdisciplinarity-methodologicalframework-going-beyond-sciencereligion-debate/

16. Nicolescu, B. (2014). From modernity to cosmodernity: Science, culture, and spirituality. New York:
State University of New York (SUNY) Press. Retrieved from https://books.google.com.ua/book $s ? h l=u k \& l r=\& i d=N C d L A g A A Q B$ AJ\&oi=fnd\&pg $=$ PR5\&dq=Nicoles cu,+B.+(2014).+From+modernity +to+cosmodernity:+Science, + cult ure,+and+spirituality.+New+York :+State+University+of+New+York $+($ SU\&ots=RleGpuAmsB\&sig $=j R c$ D2a3kgwq0wiBibCm1JJWAI9A\&r edir_esc $=\mathrm{y} \# \mathrm{v}=$ onepage $\& \mathrm{q} \& \mathrm{f}=$ false

17. Nicolescu, B. (2016). The Dark Side of Technological Singularity. New Barbarism Cybernetics and Human Knowing, 23(4), 77-81. http://dx.doi.org/10.1109\%2FMSP EC.2008.4635038

18. Nordhaus, W. D. (2015). Are we approaching an economic singularity? Information technology and the future of economic growth. Retrieved from https://www.nber. org/papers/w21547.pdf

19. Pliuta, V. (1980). Сравнительный многомерный анализ в экономических исследованиях. Методы таксономии и факторного анализа [Sravnitelnyy mnogomernyy analiz $v$ ekonomicheskikh issledovaniyakh. Metody taksonomii i faktornogo analiza]. Retrieved from https://eknigi.org/nauka_i_ ucheba/178371-sravnitelnyymnogomernyy-analiz-v-ekonomicheskih-issledovaniyah-metodytaksonomii-i-faktornogo-analiza. html
20. Ponomarenko, V., \& Gontareva, I. (2017). The system of causal connections between entrepreneurial activity and economic development. Economic AnnalsXXI, 165(5-6), 4-7. https://doi. org/10.21003/ea.V165-01

21. Sharp, B. M., Iyer, D. N., \& Brush, T. H. (2017). Executive influence on invention and commercialization: The moderating role of innovation radicalness. American Journal of Business, 32(3-4), 134151. https://doi.org/10.1108/AJB11-2016-0036

22. Vinge, V. (1993). Technological singularity. The original version of this article was presented at the VISION-21 Symposium sponsored by NASA Lewis Research Center and the Ohio Aerospace Institute, March 30-31, 1993. A slightly changed version appeared in the Winter 1993 issue of Whole Earth. Retrieved from https://edoras. sdsu.edu/ vinge/misc/singularity. html

23. Технологическая сингулярность как ближайшее будущее человечества [Tekhnologicheskaya singuliarnost kak blizhaysheye budushchee chelovechestva]. Retrieved from https://aboutspacejornal.net/2017/11/15/ технологическаясингулярность-как-б/ 